\title{
Correction to: From East to West: America as the Liberal Melting Pot of Jewish Politics
}

\author{
M. M. Silver
}

\section{Correction to:}

Chapter 10 in: A. Green, S. Levis Sullam (eds.), Jews, Liberalism, Antisemitism, Palgrave Critical Studies of Antisemitism and Racism, https://doi.org/10.1007/978-3-030-48240-4_10

The book was inadvertently published with an incorrect chapter title of captioned title as "From East to West: As the Liberal Melting Pot of Jewish Politics" whereas it should be "From East to West: America as the Liberal Melting Pot of Jewish Politics". The chapter title has been updated in the book.

The updated version of this chapter can be found at https://doi.org/10.1007/978-3-030-48240-4_10

(C) The Author(s) 2021

A. Green, S. Levis Sullam (eds.), Jews, Liberalism, Antisemitism, Palgrave Critical Studies of Antisemitism and Racism, https://doi.org/10.1007/978-3-030-48240-4_18 